\title{
EXERGY BASED OPTIMIZATION OF A BIOMASS AND SOLAR FUELLED CCHP HYBRID SEAWATER DESALINATION PLANT
}

\author{
Amir Ghasemi ${ }^{1}$, Nasim Hashemian ${ }^{1}$, Alireza Noorpoor ${ }^{1}$, Parisa Heidarnejad ${ }^{1, *}$ \\ Keywords: Exergy, CCHP, Desalination, Optimization, Solar Energy, Biomass
}

\begin{abstract}
Integrated energy systems utilizing renewable sources are a sustainable and environmentally substitution for conventional fossil fired energy systems. A CCHP hybrid seawater desalination plant with two inputs such as biomass and solar energy and four useful outputs such as cooling, heating, power and distillated water is presented and investigated in this paper. The proposed system includes evacuated tube solar collectors, biomass burner, organic rankine cycle (ORC), absorption chiller, heater and multi effect desalination system (MED). The results showed that the proposed system is able to produce $802.5 \mathrm{KW}$ as power, $10391 \mathrm{KW}$ as heating, $5658 \mathrm{KW}$ as cooling and $9.328 \mathrm{~kg} / \mathrm{s}$ distillated water. Energy efficiency of the system is $61 \%$, the exergy efficiency is $7 \%$ and the main sources of exergy destructions are biomass burner, evacuated tube solar collectors and vapor generator. Exergy optimization is carried out in order to find the optimum point of system.
\end{abstract}

\section{INTRODUCTION}

Increasing world population and demand for energy and potable water lead to burn more fossil fuels and its result is release a large amounts of greenhouse gases, particularly carbon dioxide. In order to reduce $\mathrm{CO}_{2}$ emission using renewable energy instead of fossil fuels is a main challenge for sustainable development.

CCHP systems are a kind of cogeneration systems with three outputs and CCHP hybrid seawater desalination plant can be considered as a multigeneation system since they have more than three outputs (power, heating, cooling and fresh water).

Issues like fossil fuel depletion and climate change amplify the advantages and significance of efficient multigeneration energy systems [1]. Dincer and Zamfirescu[2]showed that multigeneration systems based on renewable energies as clean and free alternatives of fossil fuels reduce fuel prices and emissions, compared to conventional systems such as cogeneration or trigeneration systems. Other studies show that exergy efficiency ofmultigeneration systems using an ORC with renewable energy source increase up to $10 \%$ and integration of two renewable energy sources such as biomass and solar energy can be beneficial with higher energy and exergy efficiency than a single renewable energy source [3,4,5]. Dincer and Zamfirescu [6] performed multigeneration renewable energy based system has better efficiency, sustainability and environment. Rubio-Mayaet et al. [7] designed a multigeneration system fuelled by natural gas, solar and gasified biomass and conclude that renewable energy is the source of the reduction of $\mathrm{CO}_{2}$ and environmental impact. Minciuc et al. [8] offered an approach for investigating of the multigeneration system and reported optimal energetic efficiency of the system. Ahmadi et al. [9] presented an exergy-based optimization of a multigeneration energy system to produce power, heating, cooling and domestic hot water. They find the best design parameters of the system considering exergy efficiency. Zamfirescu et al. [10] have examined the multigeneration system as a method of improving the exergy efficiency of the nuclear power system. Ratlamwala et al. [11] analyzed the performance of a novel integrated geothermalbased system for multigeneration, for producing cooling, heating, power generation, hot water and hydrogen. Ozlu and Dincer [12] developed a solar-wind hybrid multigeneration system and analyzed the energy and exergy efficiency of the system which were higher than equivalent single energy systems efficiencies. Sharifishourabi et al.[13] showed that a hybrid combination of renewable energy sources such as solar and wind energy can be a suitable alternative for power generation. Dube Kerme and Orfi [14] presented thermodynamic modeling of organic Rankine cycle (ORC) driven by parabolic trough solar collectors. Solar energy can be collected in many methods such as evacuated tube solar collectors (ETC) which is used in this study. Biomass is mainly derived from living or dead matter present on earth. Bagasse is a kind of biomass that is selected as one of the energy sources for the studied system and biomass fuels can be obtained from agricultural production wastes especially having

This paper was recommended for publication in revised form by Regional Editor Kwok-wing Chau 
been related to sugarcane such as Bagasse. J. Werther et al.[15] studied the processes of different agricultural wastes combustion including sugarcane. L.A.B Cortez et al. [16] did Exergy analysis in order its heat to be used in bagasse combustion. A. Bhattacharja et al. [17] studied and researched on power generation process through the utilization of bagasse gas integrating system in terms of energy and exergy, but a CCHP hybrid desalination plant driven by solar energy and bagasse combustion has not been analyzed from the viewpoint of thermodynamics.

In this paper, energy and exergy analysis of a CCHP hybrid seawater desalination plant driven by bagasse combustion and solar energy is investigated. Optimum point of system is carried out considering the exergy efficiency as an objective function.

\section{SYSTEM DESCRIPTION}

Figure 1 shows the schematic of suggested CCHP hybrid desalination system which can be divided into Evacuated Tube Collector (ETC), biomass burner, Organic Rankine Cycle (ORC), absorption chiller, heater and Multi Effect Desalination system (MED). Outputs of the proposed system are electricity, heating, cooling and fresh water.

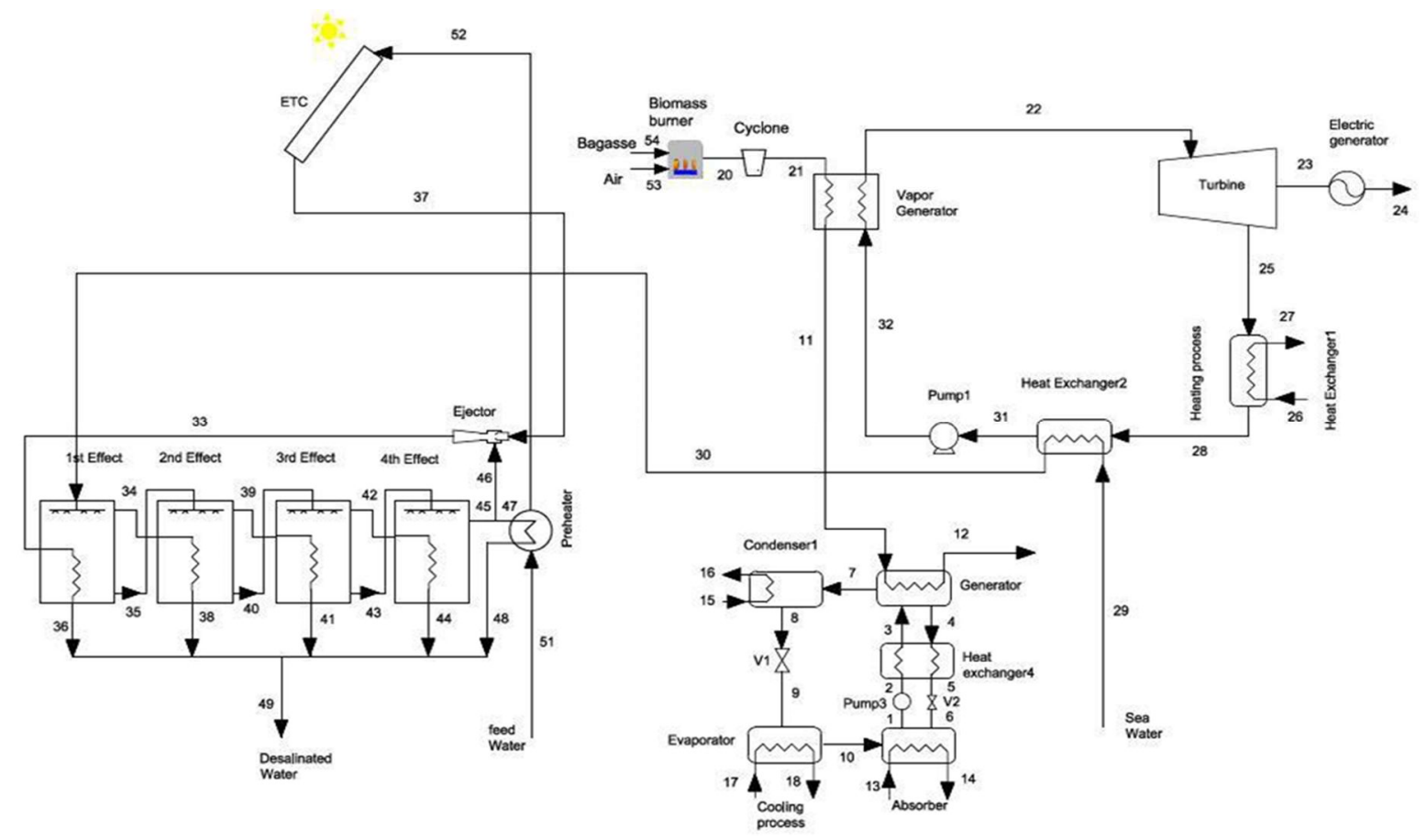

Figure 1. Schematic of CCHP hybrid desalination system

The suggested system is based on two renewable energy sources, solar energy which the solar radiation is collected through ETC, bagasse which is combusted in a biomass burner. Hot combustion gases pass through the vapor generator and enter to a single-effect absorption cycle which uses $\mathrm{LiBr}-\mathrm{H}_{2} \mathrm{O}$ to provide cooling. In the ORC the heat released from biomass burner is transferred to R123 and causes to make a superheated vapor for producing power in ORC turbine. The wasted energy of turbine is used by a heater to provide heating. In Heat Exchanger2 the remaining heat is transferred to sea water to preheat it and R123 enters to Vapor Generator to complete the cycle. Last purpose of this system is producing fresh water by a MED which contains four effects. Because the sufficient and low cost heating can be provided in this system, MED is best option compare to any other types of desalination plant. Seawater enters to first effect after preheating and a part of it is converted to fresh water. In each effect pure water is produced at lower pressure and lower temperature than the previous effect. The produced vapor of each effect feeds as the heating steam for the next effect and so on. Feed water passes through preheater and enters to ETC then steam which is produced in ETC enters to ejector. Ejector by increasing inlet steam pressure provides an appropriate pressure for the first effect of MED entrance. Data have been utilized in Khuzestan province, Iran. This province is among the most prone areas in Iran in exploitation of solar energy 
having had over 300 sunny days [18] and there are 86588 hectares under cultivation of which about 6536976 tons has been attained from 9 large sugar production factories [19].

\section{THERMODYNAMIC ANALYSIS}

Thermodynamic analysis including energy and exergy is carried out using following assumptions:

- The reference-environment state has a temperature

$\mathrm{T}_{0}=298 \mathrm{~K}$ and a pressure $\mathrm{P}_{0}=100 \mathrm{KPa}$.

- The changes in kinetic and potential energy and exergy terms are negligible.

- $\quad \mathrm{HHV}$ for bagasse is $16793 \mathrm{KJ} / \mathrm{Kg}$

- $\quad$ The higher heating value (HHV) is the primary contributor to the chemical exergy of a biomass fuel and obtained from bellow equation[20]:

$$
\frac{e_{f}^{-c h}}{H H V} \approx 1.00-1.04
$$

First and second thermodynamic laws have been to each component as below [21]:

$$
\sum \dot{m}_{\text {in }}=\sum \dot{m}_{\text {out }}
$$

$$
\sum \dot{Q}-\sum \dot{W}=\sum \dot{m}_{\text {out }} h_{\text {out }}-\sum \dot{m}_{\text {in }} h_{\text {in }}
$$

$$
\dot{E} x_{Q}+\sum_{i} \dot{m}_{i} e x_{i}=\sum_{e} \dot{m}_{e} e x_{e}+\dot{E} x_{W}+\dot{E} x_{D}
$$

The exergy of a substance is often divided into four components. Two common ones are physical and chemical exergy. The two others, kinetic and potential exergy, are assumed to be negligible here:

$$
\begin{aligned}
& \dot{E} x_{p h}=\left(h-h_{0}\right)-T_{0}\left(S-S_{0}\right) \\
& \dot{E} x_{c h}=\sum e x_{k} \dot{E} x_{c h}^{k}+R T_{0} \sum x_{k} \ln x_{k}
\end{aligned}
$$

Bagasse combustion equation based on wet is as following [17]:

$[0.268 \mathrm{C}+0.239 \mathrm{H} 2+0.099 \mathrm{O} 2+0.394 \mathrm{H} 2 \mathrm{O}+\mathrm{Ash}]+[1.075 \mathrm{~N} 2+0.289 \mathrm{O} 2+0.013 \mathrm{Ar}] \rightarrow[0.268 \mathrm{CO} 2+0.633$
$\mathrm{H} 2 \mathrm{O}+1.075 \mathrm{~N} 2+0.013 \mathrm{Ar}]$

\section{RESULTS AND DISCUSSION}

Thermodynamic modeling is implemented through Engineering Equation Software (EES) [22] using input data which is shown in Table 1, and the result of thermodynamic modeling is presented in Table 2. The system is proposed for locating in Ahwaz, Iran since it has sufficient sources of bagasse and solar radiation. Average daily solar radiation is extracted from NASA internet site [23]. 
Table 1. Input data for thermodynamic modeling

\begin{tabular}{|c|c|}
\hline Parameters & Values \\
\hline Turbine inlet temperature & $130{ }^{0} \mathrm{C}$ \\
\hline Turbine inlet pressure & $700 \mathrm{KPa}$ \\
\hline Turbine pressure ratio & 2.5 \\
\hline $\begin{array}{c}\text { Heat exchanger temperature } \\
\text { difference }\end{array}$ & $10^{\circ} \mathrm{C}$ \\
\hline $\begin{array}{c}\text { Temperature difference of } \\
\text { each effect of MED }\end{array}$ & $5{ }^{0} \mathrm{C}$ \\
\hline Evaporation Temperature & $1.5^{\circ} \mathrm{C}$ \\
\hline $\begin{array}{c}\text { Condenser temperature } \\
\text { difference }\end{array}$ & $5{ }^{\circ} \mathrm{C}$ \\
\hline
\end{tabular}

Table 2. Result of thermodynamic modeling for proposed system

\begin{tabular}{|c|c|c|c|c|c|}
\hline $\begin{array}{l}\text { Number } \\
\text { of } \\
\text { Stream }\end{array}$ & $\begin{array}{c}\mathrm{T} \\
\left({ }^{0} \mathrm{C}\right)\end{array}$ & $\begin{array}{c}P \\
(\mathbf{k P a})\end{array}$ & $\begin{array}{c}\text { h } \\
(\mathrm{kJ} / \mathrm{kg})\end{array}$ & $\begin{array}{c}\mathrm{S} \\
(\mathrm{kJ} / \mathrm{kgK})\end{array}$ & $\begin{array}{l}\mathbf{E}^{\text {total }} \\
(\mathrm{kJ} / \mathrm{s})\end{array}$ \\
\hline 1 & 34.6 & 0.6812 & 93.07 & 0.1977 & 283.6 \\
\hline 2 & 34.6 & 7.424 & 97.19 & 0.1977 & 287.7 \\
\hline 3 & 67.6 & 7.424 & 159 & 0.3989 & 289.5 \\
\hline 4 & 80 & 7.424 & 185.6 & 0.4665 & 553.3 \\
\hline 5 & 45.62 & 7.424 & 123.2 & 0.264 & 551.3 \\
\hline 6 & 35.62 & 0.6812 & 123.2 & 0.202 & 569.7 \\
\hline 7 & 80 & 7.424 & 2649 & 8.481 & 126.6 \\
\hline 8 & 40.11 & 7.424 & 168 & 0.5737 & 1.486 \\
\hline 9 & 1.5 & 0.6812 & 168 & 0.6116 & 9.795 \\
\hline 10 & 1.5 & 0.6812 & 2503 & 9.114 & 208.3 \\
\hline 11 & 87.25 & 101.3 & 361.2 & 5.886 & 5.729 \\
\hline 12 & 25 & 101.3 & 298.6 & 5.695 & 0.0211 \\
\hline 13 & 35 & 101.3 & 146.7 & 0.5049 & - \\
\hline 14 & 25 & 101.3 & 104.8 & 0.3669 & - \\
\hline 15 & 25 & 101.3 & 104.8 & 0.3669 & - \\
\hline 16 & 30 & 100 & 125.8 & 0.4365 & - \\
\hline 21 & 150 & 101.3 & 424.8 & 6.049 & - \\
\hline
\end{tabular}


Table 2. Result of thermodynamic modeling for proposed system (cont.)

\begin{tabular}{|c|c|c|c|c|c|}
\hline $\begin{array}{c}\text { Number } \\
\text { of } \\
\text { Stream }\end{array}$ & $\begin{array}{c}\mathrm{T} \\
\left({ }^{\circ} \mathrm{C}\right)\end{array}$ & $\begin{array}{c}P \\
(\mathrm{kPa})\end{array}$ & $\begin{array}{c}\text { h } \\
(\mathrm{kJ} / \mathrm{kg})\end{array}$ & $\begin{array}{c}\mathrm{S} \\
(\mathrm{kJ} / \mathrm{kgK})\end{array}$ & $\begin{array}{c}\text { Etotal } \\
(\mathrm{kJ} / \mathrm{s})\end{array}$ \\
\hline 22 & 130 & 700 & 470.8 & 1.772 & 41.92 \\
\hline 25 & 105 & 280 & 455.5 & 1.779 & 24.47 \\
\hline 26 & 29.93 & 150 & 125.5 & 0.4355 & 1394 \\
\hline 27 & 59.93 & 150 & 251 & 0.8302 & 1402 \\
\hline 28 & 59.23 & 280 & 262.5 & 1.206 & 2.222 \\
\hline 29 & 25 & 101.3 & 99.01 & 0.3459 & 0 \\
\hline 30 & 49.23 & 101.3 & 195.4 & 0.657 & 3.682 \\
\hline 31 & 35 & 280 & 236.7 & 1.125 & 0.3335 \\
\hline 32 & 35.28 & 700 & 237.1 & 1.126 & 0.6306 \\
\hline 33 & 133.3 & 297.9 & 2725 & 6.994 & 645.1 \\
\hline 34 & 99.86 & 100.8 & 2675 & 7.356 & 487.8 \\
\hline 35 & 99.05 & 101.3 & 388.9 & 1.21 & 31.27 \\
\hline 36 & 133.3 & 297.9 & 560.6 & 1.67 & 67.55 \\
\hline 37 & 138.9 & 350 & 2732 & 6.939 & 668.3 \\
\hline 38 & 99.86 & 100.8 & 418.5 & 1.305 & 33.99 \\
\hline 39 & 99.72 & 100.3 & 2675 & 7.358 & 487.1 \\
\hline 40 & 98.63 & 101.3 & 379.6 & 1.175 & 30.91 \\
\hline 41 & 99.72 & 100.3 & 417.9 & 1.304 & 33.87 \\
\hline 42 & 99.58 & 99.8 & 2675 & 7.36 & 486.4 \\
\hline 43 & 98.1 & 101.3 & 367.7 & - & 30.83 \\
\hline 44 & 99.58 & 99.8 & 417.3 & 1.302 & 33.75 \\
\hline 45 & 99.44 & 99.3 & 2675 & 7.361 & 485.7 \\
\hline 46 & 99.44 & 99.3 & 2675 & 7.361 & 485.7 \\
\hline 47 & 99.44 & 99.3 & 2675 & 7.361 & 485.7 \\
\hline 48 & 99.44 & 99.3 & 2227 & 6.16 & 396.1 \\
\hline 50 & 25 & 350 & 105.1 & 0.3669 & 0.2494 \\
\hline 51 & 89.44 & 350 & 374.8 & 1.186 & 25.91 \\
\hline 52 & 25 & 101.3 & 104.8 & 0.3669 & - \\
\hline
\end{tabular}


Based on these data, the performance of the system is evaluated and is presented in Table 3 . The mentioned exergy balance is applied for each component of the system and the exergy destruction rate and exergy efficiency system components are shown in Table 4.

Table 3. Performance of the system

\begin{tabular}{ll}
\hline Parameters & values \\
\hline Thermal efficiency & $61 \%$ \\
Exergy efficiency & $7 \%$ \\
Cooling load & $5658 \mathrm{KW}$ \\
Heating load & $10391 \mathrm{KW}$ \\
Power & $802.5 \mathrm{KW}$ \\
Fresh water & $9.328 \mathrm{Kg} / \mathrm{s}$ \\
\hline
\end{tabular}

Figure 2, shows the amount of exergy destruction for some components of system which has the considerable share in total exergy destruction of the system in comparison to others. As it is shown, biomass burner $(21539 \mathrm{KW})$, ETC $(9829 \mathrm{KW})$ and vapor generator $(741.7 \mathrm{KW})$ are the major sources of exergy destruction rate. In the biomass burner, the irreversibility is because of occurring combustion in it and combustion is one of the sources of irreversibility in a process. In the ETC, the irreversibility created is due to large temperature difference between solar heat and fluid in the tubes. The main reason of irreversibility in vapor generator is related to the stream-tostream heat transfer. Since the amount of irreversibility of remaining components is negligible, their exergy destruction is not considered here.

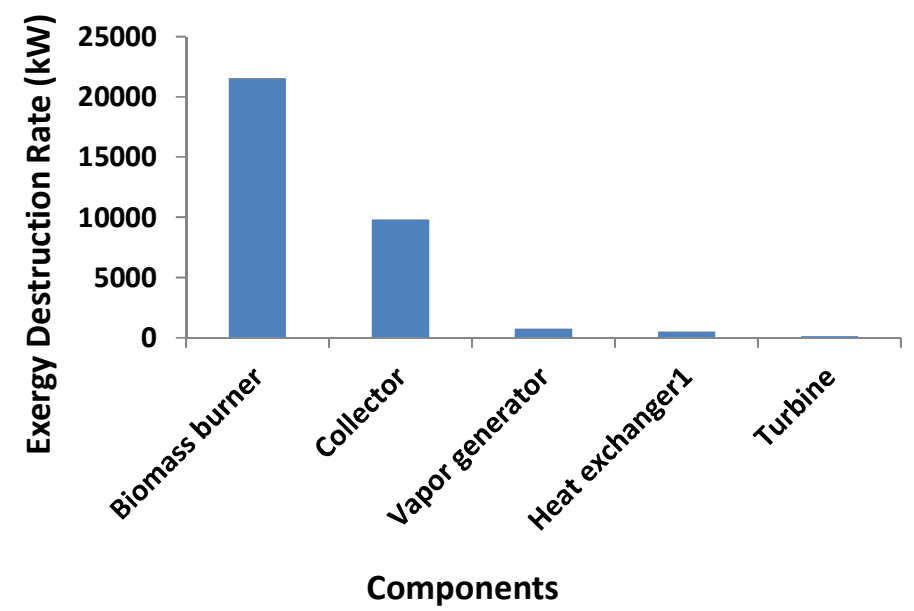

Figure 2. Some selected components exergy destruction rate $(\mathrm{kW})$

Three independent variables including turbine inlet temperature, turbine inlet pressure and Heat Exchanger1 temperature difference are varied to investigate their effects on system total exergy efficiency and is illustrated in Figure 3, 4,5. 


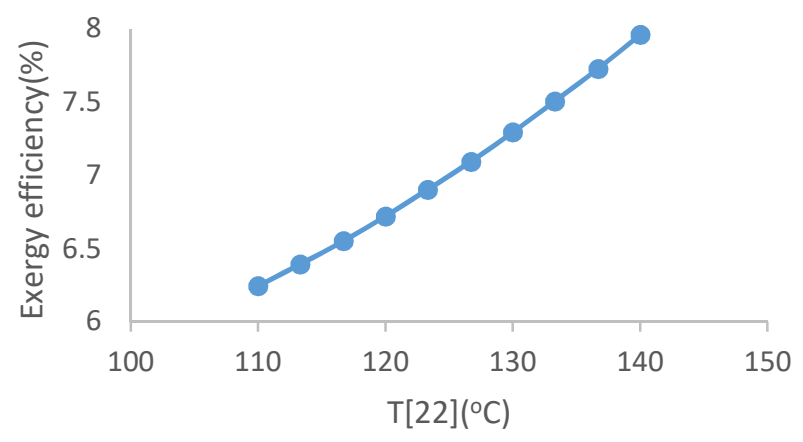

Figure 3. Effect of turbine inlet temperature on exergy efficiency

Figure 3 demonstrates the effect of turbine inlet temperature on exergy efficiency of the system, by increasing turbine inlet temperature between $110 \mathrm{C}$ and $140 \mathrm{C}$ exergy efficiency increases about $27 \%$.

The effect of variation of turbine inlet pressure on exergy efficiency of the system is shown in Figure 4,as turbine inlet pressure varies between $650 \mathrm{kPa}$ and $800 \mathrm{kPa}$, exergy efficiency of the system decreases about $5 \%$.This decrement is due to decrement of amount of electricity and heating power produced by multigeneration system.

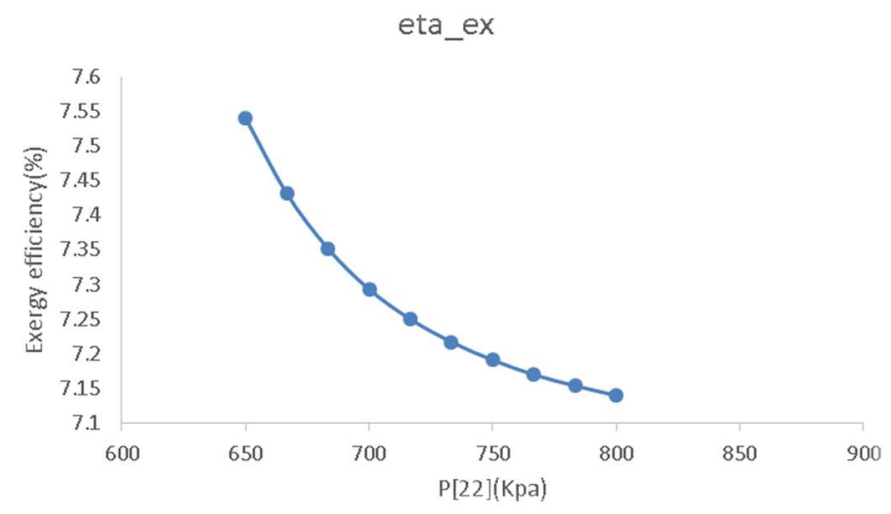

Figure 4. Effect of turbine inlet pressure on exergy efficiency

Figure 5 represent the effect of Heat Exchanger1 temperature difference on the exergy efficiency of the system, as it can be observed by increasing heat exchanger 1 temperature difference between 5 and 15, exergy efficiency of the system decreases because of increment in total exergy destruction of the system.

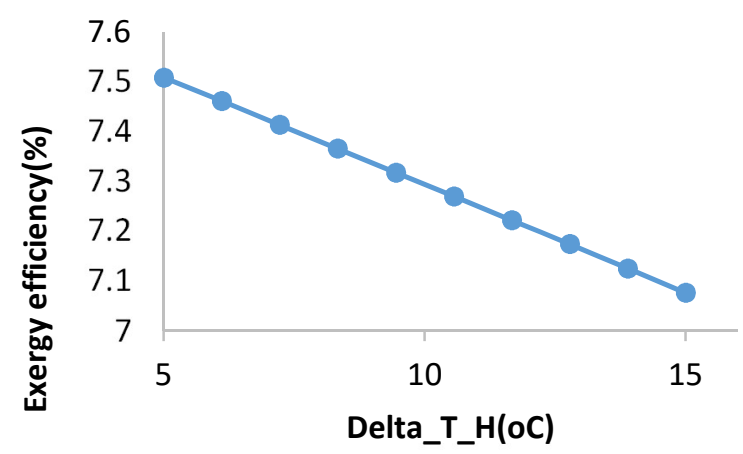

Figure 5. Effect of temperature difference of heat exchanger1 on exergy efficiency 


\section{OPTIMIZATION}

Optimization is carried out to determine the best design parameters of the system and different objectives can be defined for this purpose. For this purpose genetic algorithm (GA) through EES software is used for optimization of CCHP hybrid desalination plant. The selected decision variables are turbine inlet temperature (T[22]), turbine inlet pressure $(\mathrm{P}[22])$ and Temperature difference of Heat Exchanger $1\left(\Delta \mathrm{T}_{\mathrm{HE} 1}\right)$. Table 4 shows the base case and optimal case values of the decision variables and objective functions.

Table 4. Exergy destruction rate and exergy efficiency of some system components

\begin{tabular}{|c|c|c|}
\hline Component & Exergy destruction rate $\left(E \dot{x}_{D}\right)$ & Exergy efficiency $(\varepsilon)$ \\
\hline Turbine & $E \dot{x}_{D, t u r b}=\left(E \dot{x}_{22}-E \dot{x}_{25}\right)-\dot{W}_{t u r b}$ & $\varepsilon_{\text {turb }}=\frac{\dot{W}_{\text {turb }}}{\left(E \dot{x}_{22}-E \dot{x}_{25}\right)}$ \\
\hline Heat Exchanger1 & $E \dot{x}_{D, H E 1}=\left(E \dot{x}_{25}-E \dot{x}_{28}\right)-\left(E \dot{x}_{27}-E \dot{x}_{26}\right)$ & $\varepsilon_{H E 1}=\frac{\left(E \dot{x}_{27}-E \dot{x}_{26}\right)}{\left(E \dot{x}_{25}-E \dot{x}_{28}\right)}$ \\
\hline Pump1 & $E \dot{x}_{D, \text { pump } 1}=\dot{W}_{\text {pump } 1_{1}}-\left(E \dot{x}_{32}-E \dot{x}_{31}\right)$ & $\varepsilon_{\text {pump } 1}=\frac{\left(E \dot{x}_{32}-E \dot{x}_{31}\right)}{\dot{W}_{\text {pump }}}$ \\
\hline Preheater & $E \dot{x}_{D, P H}=\left(E \dot{x}_{48}-E \dot{x}_{47}\right)-\left(E \dot{x}_{52}-E \dot{x}_{51}\right)$ & $\varepsilon_{P H}=\frac{\left(E \dot{x}_{52}-E \dot{x}_{51}\right)}{\left(E \dot{x}_{48}-E \dot{x}_{47}\right)}$ \\
\hline Collector & $E \dot{x}_{D, \text { coll }}=E \dot{x}_{s}-\left(E \dot{x}_{37}-E \dot{x}_{52}\right)$ & $\varepsilon_{D, \text { coll }}=\frac{\left(E \dot{x}_{37}-E \dot{x}_{52}\right)}{E \dot{x}_{s}}$ \\
\hline Ejector & $E \dot{x}_{D, e j c}=\dot{m}_{37}\left(e x_{37}-e x_{33}\right)-\dot{m}_{46}\left(e x_{33}-e x_{46}\right)$ & $\varepsilon_{e j c}=\frac{\dot{m}_{46}\left(e x_{33}-e x_{46}\right)}{\dot{m}_{37}\left(e x_{37}-e x_{33}\right)}$ \\
\hline Absorber & $E \dot{x}_{D, a b s}=\left(E \dot{x}_{10}+E \dot{x}_{1}-E \dot{x}_{6}\right)-\left(E \dot{x}_{13}-E \dot{x}_{14}\right)$ & $\varepsilon_{a b s}=\frac{\left(E \dot{x}_{13}-E \dot{x}_{14}\right)}{\left(E \dot{x}_{10}+E \dot{x}_{1}-E \dot{x}_{6}\right)}$ \\
\hline Evaporator & $E \dot{x}_{D, \text { eva }}=\left(E \dot{x}_{9}-E \dot{x}_{10}\right)-E \dot{x}_{Q, \text { eva }}$ & $\varepsilon_{e v a}=\frac{E \dot{x}_{Q, e v a}}{\left(E \dot{x}_{9}-E \dot{x}_{10}\right)}$ \\
\hline
\end{tabular}


Table 5. Base case and optimal case values of the decision variables and objective functions

\begin{tabular}{|c|c|c|}
\hline Parameters & Base case & Optimal case \\
\hline $\begin{array}{c}\text { Exergy efficiency } \\
(\%)\end{array}$ & 7 & 8.5 \\
\hline $\begin{array}{c}\text { Turbine inlet } \\
\text { pressure }(\mathrm{kPa})\end{array}$ & 700 & 657.5 \\
\hline $\begin{array}{c}\text { Turbine inlet } \\
\text { temperature }\left({ }^{\circ} \mathrm{C}\right)\end{array}$ & 130 & 137 \\
\hline $\begin{array}{c}\text { Temperature } \\
\text { difference of Heat } \\
\text { Exchanger. } 1\left({ }^{\circ} \mathrm{C}\right)\end{array}$ & 10 & 5 \\
\hline
\end{tabular}

\section{CONCLUSION}

The present work proposes a biomass and solar based CCHP hybrid desalination system which produces power, cooling, heating and fresh water. Energy and exergy analysis is applied to identify the components with high exergy destruction rate and calculate the exergy efficiency of the system. Results show that biomass burner, evacuated tube solar collectors and vapor generator are the major sources of exergy destruction thus it is necessary to have better design for these components to minimize the system exergy destruction. By increasing turbine inlet temperature, decreasing Turbine inlet pressure and decreasing Temperature difference of Heat Exchanger.1 exergetic performance of the system improves. The exergy efficiency is $7 \%$.Optimization is carried out through EES software using GA and results show that exergy efficiency in optimum case improves $21 \%$ in comparison to base case value.

\section{NOMENCLATURE}

$\begin{array}{ll}\mathrm{A}_{\text {coll }} & \text { Solar collector area, } \mathrm{m}^{2} \\ \mathrm{Ex} & \text { Specific exergy, } \mathrm{kJ} / \mathrm{kg} \\ \mathrm{E} \dot{\mathrm{X}} & \text { Exergy, } \mathrm{kW} \\ \mathrm{G}_{\mathrm{t}} & \text { Total instantaneous radiation, } \mathrm{W} / \mathrm{m}^{2} \\ \mathrm{H} & \text { Specific enthalpy, } \mathrm{kJ} / \mathrm{kg} \\ \mathrm{In} & \text { Inlet } \\ \dot{\mathrm{m}} & \text { Mass flow rate, } \mathrm{kg} / \mathrm{s} \\ \text { out } & \text { Outlet } \\ \mathrm{P} & \text { Pressure, bar } \\ \dot{Q} & \text { Heat transfer rate, } \mathrm{kW} \\ \mathrm{R} & \text { Gas constant, } \mathrm{kJ} / \mathrm{kgK} \\ \mathrm{s} & \text { Specific entropy, } \mathrm{kJ} / \mathrm{kgK} \\ \mathrm{T} & \text { Temperature, }{ }^{\circ} \mathrm{C} \\ \dot{\mathrm{W}} & \text { Work rate, } \mathrm{kW} \\ x_{k} & \text { Number of molecules of gas } \mathrm{k} \text { molecules }\end{array}$

\section{Subscripts}

\section{0}

$\mathrm{ch}$

$\mathrm{D}$

HHV

ph

Turb
Ambient

Chemical

Destruction

Higher Heating Value

Physical

Turbine

\section{Greek symbols}

$\varepsilon$

Exergy efficiency

Abbreviations

CCHP

Combined Cooling, Heating and Power 
EES Engineering Equation Solver

ORC Organic Rankine Cycle

\section{REFERENCES}

[1] Ahmadi, Pouria, Ibrahim Dincer, and Marc A. Rosen. "Thermodynamic modeling and multi-objective evolutionary-based optimization of a new multigeneration energy system." Energy Conversion and Management 76 (2013): 282-300.

[2] Dincer, I., Zamfirescu, C., 2011. Sustainable Energy Systems and Applications.Springer.

[3] Al-Sulaiman, F.A., Dincer, I., Hamdullahpur, F., 2012. Energy and exergy analyses of a biomass trigeneration system using an organic Rankine Cycle. Energy 45, 975-985.

[4] Ozturk, M., Dincer, I., 2013. Thermodynamic assessment of an integrated solar power tower and coal gasification system for multigeneration purposes.Energy Convers. Manage. 76, 1061-1072.

[5]Ozturk, M., Dincer, I., 2013. Thermodynamic analysis of a solar-based multigeneration system with hydrogen production. Appl. Therm. Eng.51, 1235-1244.

[6] I. Dincer, C. Zamfirescu, Renewable-energy-based multigeneration systems, Int. J. Energy Res. 36 (15) (2012) $1403 \mathrm{e} 1415$.

[7] C. Rubio-Mayaet, J. Uche-Marcuello, A. Martinez-Gracia, A.A. Bayod-Rujula,Design optimization of a polygeneration plant fuelled by natural gas and renewable energy sources, Appl. Energy 88 (2) (2011) $449 \mathrm{e} 457$.

[8] E. Minciuc, O.L. Corre, V. Athanasovici, M. Tazerout, I. Bitir, Thermodynamic analysis of trigeneration with absorption chilling machine, Applied Thermal Engineering 23 (2003) 1391e1404.

[9] Ahmadi P, Rosen MA, Dincer I. Multi-objective exergy-based optimization of a polygeneration energy system using an evolutionary algorithm. Energy 2012;46:21-31.

[10] C. Zamfirescu, G.F. Naterer, I. Dincer, Upgrading of waste heat for combined power and hydrogen production with nuclear reactors, Journal of Engineering for Gas Turbines and Power 132 (2010) 1e9.

[11] Ratlamwala T, Dincer I, Gadalla MA. Performance analysis of a novel integrated geothermal-based system for multi-generation applications. Applied Thermal Engineering 2012;40:71e9.

[12] Ozlu S. and Dincer I., Development and analysis of a solar and wind energy based multigeneration system, Solar Energy, 122(2015). 1279-1295.

[13] Sharifishourabi M, Alimoradiyan H, Atikol U. Modeling of Hybrid Renewable Energy System: The Case Study of Istanbul, Turkey. Journal of Thermal Engineering, (2016), 990-994.

[14] kerme E, Orfi j. Exergy-based Thermodynamic Analysis of Solar Driven Organic Rankine Cycle. Journal of Thermal Engineering, (2015), 192-202.

[15] J.Werther,M.Saenger,E.Hartge, Combustion of agricaltural residues. Journal of progress in energy and combustion science, 2006

[16]L.A.B. Cortez,E.O.Gomez,Amehod for Exergy Analysis of Sugercane Bagasse Boiler, Brazilian Journal of chemical Engineering.Sao Paulo,1998.

[17]A.Bhattacharya, D.Manna,B.Pual, A.Data, Biomass integrated gasification with supplementry biomass firing, Journal of Energy, (2011) 2599-2610

[18]Khuzestan Central Organization of Agriculture, www.kaj.maj.ir/

[19] Iran Statistics Agency, www.amar.org.ir/

[20] Frangopoulos, Christos A., ed. Exergy, energy system analysis, and optimization. Eolss Publishers, 2009.

[21] A.T. Bejan,satsaromis,G.Moran, M.J,.Thermal Design and Optimization, John Wiley \& sons In, New York. 1996.

[22] www.fchart.com. Engineering equation solver (EES).

[23] https://eosweb.larc.nasa.gov/cgi-bin/sse/daily.cgi 